of the size of the groups or the number of companions.

Figure 4 shows the mean frequencies of responses to the green and blue stimuli by the various number of companions in the groups. A significant difference $(p<.05)$ was found among the four groups. From the multiple comparisons, the groups with four and three Ss did not differ significantly, nor did the two-Ss group and the isolated group $(\mathrm{p}>.05)$. However, all other comparisons were significant $(\mathrm{p}<.05)$.

As in Experiment 1, the rapid and continued decline in responses to the green stimulus on the nonreinforced days dominate Fig. 4. In terms of the mean frequencies, these data may be further interpreted as extinction and are further inconsistent with the interpretation of imprinting.

\section{GENERAL DISCUSSION}

If the data are transformed into percentage of responses, there are some evidences for a food imprinting interpretation. However, food imprinting is a function of both unrestricted social and visual interaction among companions and the number of companions. It is apparent that the presence of other chicks is absolutely essential for food imprinting to occur.

If, on the other hand, the data are analyzed in terms of the mean frequency of responses, there are no evidences to support the food imprinting interpretation. However, the data can be clearly interpreted in terms of association learning processes. From an associative learning interpretation, the various extinction curves are a function of the various experimental conditions. It appears that the various interpretations may be a function of the analysis that was utilized. At present, as parsimony would dictate, there are no dissimilarities between food imprinting and associative learning.

\section{REFERENCES}

HESS, E. H. Imprinting in birds. Science, 1964, 146, 1128-1139.

MEYER, M. E., \& FRANK. L. H. Food imprinting in the domestic chick: A reconsideration. Psychonomic Science, in press.

TOLMAN, C. W. Social facilitation of feeding behavior in the domestic chick. Animal Behaviour, 1964, 12, 245-251.

TOLMAN, D. W., \& WILSON, G. F. Social feeding in domestic chicks. Animal Behaviour, $1965,13,134-142$

\title{
The effect of magnesium pemoline on
}

\section{discrimination learning and exploratory}

behavior $^{1}$

\begin{abstract}
CLIFFORD KNOX and PAUL GENDREAU, ${ }^{2}$ Trent University, Peterborough, Ont., Canada
\end{abstract}

\begin{abstract}
A drug group was injected interperitoneally with $10 \mathrm{mg} / \mathrm{kg}$ body weight of magnesium pemoline in tragacanth and a control group received the vehicle substance only. The animals were tested on a two-alternative forced choice brightness discrimination task and an open-field test of exploratory behavior. The drug group (1) increased exploratory behavior; (2) produced superior percentage correct discrimination performance; and (3) decreased running speed. The results indicated that the drug, besides having considerable stimulant properties, enhanced learning. Also, a previous study on magnesium pemoline and discrimination learning was reanalyzed and superior discrimination was found for the drug group.
\end{abstract}

Following the report of Glasky \& Simon (1966) on the facilitating effects of magnesium pemoline (MP) on RNA synthesis, considerable attention has focused on the influence of MP learning. Adams, Crawford, \& Lee (1969) have noted that whereas several studies (Beach \& Kimble, 1967; Filby, Szara, \& Salzman, 1967; Frey \& Polidora, 1967; Kulkami, 1967; Plotnikoff, 1966; Thompson \& Knudson, 1968) have reported MP facilitated performance on conditioned avoidance tasks, considerable disagreement has existed as to whether or not the powerful stimulant properties of MP influenced learning or performance. Further, Chase \& Rescorla (1968), Cylert, Mayer, \& Chapman (1967, and Gurowitz, Lubar, Ain, \& Gross (1967) claimed MP failed to enhance conditioned avoidance. More recently, Bridge \& Hatton (1969) have emphasized the need to distinguish between performance and learning effects of MP. Secondly, they argued that the use of positive reinforcement avoided visceral imbalances caused by shock used in previous MP studies. The present study examined stimulant and learning effects of MP on a two-alternative forced choice (2-AFC) brightness discrimination task (Green \& Swets, 1966) using positive reinforcement. The index of discrimination employed, percentage ratio of correct to incorrect responses, offered a measure of discrimination learning relatively free of response bias caused by MP stimulant effects (Bridge \& Hatton, 1969). Open-field exploratory behavior was the dependent variable for measuring MP stimulant properties. Other indices of MP influence on performance, response latency, and trials to criterion were also recorded.

Of the two studies reporting MP effects on a positively reinforced discrimination task, only Bridge and Hatton found MP to facilitate leaming besides performance. Cooper, Potts, Morse, \& Black (1969) found MP to affect performance but did not analyze percentage-correct discrimination. As part of the present study, the Cooper et al (1969) experiment was reanalyzed on the latter index.

\section{SUBJECTS}

Thirty Sprague-Dawley hooded rats served as Ss. The animals were 70-90 days of age and weighed from 212.0 to $262.0 \mathrm{~g}$. The rats were housed in individual cages and were not handled prior to the experiment.

A Y-maze was used to obtain error and time scores for the brightness discrimination task. The maze arms and the startbox were painted gray, while one goalbox was black, the other white. The maze was $4 \frac{1}{2}$ in wide, $5 \frac{1}{4}$ in. deep, and $30 \mathrm{in}$. from the choice point to the end of the start- and goalboxes. Small metal slides separated the start and goalboxes from the maze arms. The arms and boxes were covered by $1 / 8$-in. clear Plexiglas, which was hinged near the choice point.

Open-field exploratory behavior was measured with a Hebb-Williams maze (Lubar, Boitano, Gurowitz, \& Ain, 1967). The floor of the maze was divided into 36 5-in. squares. The floor and the sides of the Hebb-Williams maze was constructed of 3/4-in. plywood and was left unpainted. The maze floor was bounded only by the four outside walls.

\section{PROCEDURE}

The Ss were divided randomly into two groups. Each $\mathrm{S}$ was weighed on a Mettler electric balance. Drug calculations were based on body weight. The drug was suspended in a $0.3 \%$ tragacanth vehicle. Each $S$ received an interperitoneal (IP) injection of $10 \mathrm{mg} / \mathrm{kg}$ magnesium pemoline $30 \mathrm{~min}$ before the start of each test. A $10-\mathrm{mg} / \mathrm{kg}$ dosage level was chosen as it had been found to be effective in previous MP studies (e.g., Cooper et al, 1969). Control Ss received $2 \mathrm{cc}$ of the $0.3 \%$ solution of gum tragacanth as a placebo injection. The open-field test was conducted a day prior to running the 2-AFC task. 
Table 1

Mean Values of MP Rats and Controls on (A) Response Latency, (B) Trials to Criterion, and (C) Percentage Correct Responses on a 2-AFC Brightness Discrimination Task

\begin{tabular}{lll}
\hline & \multicolumn{1}{c}{ MP } & Controls \\
\hline Response Latency & $17.4^{* *}$ & 34.9 \\
Trials to Criterion & 34.3 & 43.9 \\
Percentage Correct & $65.5^{*}$ & 60.6 \\
\hline
\end{tabular}

* significant at .05 level

** significant at .OI level

In the open-field activity test, each $\mathrm{S}$ was placed in the Hebb-Williams maze for a 5 -min interval. During this period, a quantitative measure was obtained by counting the number of squares the animal entered. A square was counted if $S$ placed either foot into it. The maze floor was wiped with a mild disinfectant after each $S$ was tested.

In the discrimination task each $S$ received 20 massed trials per day. During the discrimination task, Ss were rewarded for a correct discrimination with two pellets of Noyes No. 10 specialized rat food moistened with water for choosing the black goalbox. Each $S$ remained in the goalbox for $15 \mathrm{sec}$, whether he made a correct choice or not, then was carried by hand back to the startbox where he remained for another $30 \mathrm{sec}$ before the start of the next trial.

A Gellerman series was used to randomize right-left choices for reinforcement on the $2-\mathrm{AFC}$ task. Time scores were obtained from the moment the animal was freed from the goalbox by the $E$ releasing the slide until his nose entered the goalbox of his choice. An error was defined by an incorrect color choice and recorded when the animal's nose entered the goalbox. Each animal was required to make 9 of 10 consecutive responses without error to reach criterion. The maze was disinfected after each $S$ had completed a block of test trials.

Two days before the test sessions began, all Ss were placed on a deprivation feeding schedule which allowed $30 \mathrm{~min}$ free feeding each day. Water was available ad lib. This deprivation schedule prevailed throughout the testing period.

\section{RESULTS}

Two-tailed t-test comparisons for independent samples were carried out on the data gathered from 14 control and 13 drug rats. One control and two drug rats remained immobilized in the startbox and were not included in the final analysis.

Exploratory Behavior

Magnesium pemoline rats explored significantly more squares than did controls $(t=3.3, \mathrm{df}=25, \mathrm{p}<.01)$. The MP rats traversed an average of 151.4 squares in the Hebb-Williams maze, the controls, 97.4 squares.

\section{Discrimination Behavior}

Magnesium pemoline rats took significantly less time (measured in seconds) to reach the reward box from the startbox $(t=5.3, d f=25, p<.01)$.

Magnesium pemoline rats had fewer trials to criterion; the effect just failed to reach significance at the .05 level $(t=1.9$, $\mathrm{df}=25, \mathrm{p}>.05$ ).

Percentage correct responses in the brightness discrimination task, the ratio of percentage correct/incorrect responses, was significantly greater for MP rats $(t=2.1$, $\mathrm{df}=25, \mathrm{p}<.05$ ). Table 1 summarizes the mean values for MP control rats on running speed, trials to criterion and percentage correct discrimination.

Discrimination Behavior, Cooper et al

Percentage correct performance of 5, 10, and $15 \mathrm{mg} / \mathrm{kg}$ MP rats in the Cooper et al (1969) study were scored and analyzed. MP dosages of 10 and $15 \mathrm{mg} / \mathrm{kg}$ produced superior discrimination performance $(\mathrm{t}=7.3,4.2$, respectively, $\mathrm{df}=4, \mathrm{p}<.01)$ compared to placebo rats' performance. Mean percentage correct responding for 10 and $15 \mathrm{mg} / \mathrm{kg}$ rats was 71.6 and 59.0 , respectively. Control rats' percentage was 52.0. An MP dosage of $5 \mathrm{mg} / \mathrm{kg}$ of M.P had little effect on discrimination $(t<1)$.

\section{DISCUSSION}

Consistent with previous studies, the stimulant properties of MP was found to have considerable performance effects. MP rats demonstrably explored more in the Hebb-Williams open-field test and took far less time to reach the goalbox in the 2-AFC brightness discrimination task. In addition to the stimulant properties of MP, learning was enhanced as MP rats not only made more correct choices but also fewer incorrect choices on the 2-AFC task in the present experiment and also in the Cooper et al (1969) study.

In contrast to the studies on MP and conditioned avoidance, the authors, along with Bridge and Hatton (1969) and Cooper et al (1969), have found quite similar results with MP and a positive reward 2-AFC task in regard to the drug's effects on learning per se. Also of note is that MP dosages of 10,15 , or $20 \mathrm{mg} / \mathrm{kg}$ seemed particularly effective in the above studies.

Finally, one problem with positive reward studies is that MP has been found to decrease food intake (Pizzi \& See, 1968), thus the discrimination learning may have been attenuated somewhat because of this fact.

\section{REFERENCES}

ADAMS, P. M., CRAWFORD, F. T., \& LEE, W.
G. The effects of magnesium pemoline upon repeated acquisition and extinction of a bar press response. Psychonomic Science, 1969, 14, 101-102.

BEACH, G., \& KIMBLE, D. P. Activity and responsivity in rats after magnesium pemoline injection. Science, 1967, 155, 698-701.

BRIDGE, J. G., \& HATTON, G. I. Magnesium pemoline: Effects of brightness discrimination using positive reward. Psychonomic Science, $1969,15,52-53$.

CHASE, T. C., \& RESCORLA, R. A. The effect of magnesium pemoline on learning an active avoidance-passive avoidance discrimination. Psychonomic Science, 1968, 10, 87-88.

COOPER, B. R., POTTS, W. J., MORSE, D. L., \& BLACK, W. C. The effects of magnesium pemoline, caffeine and picrotoxin on a food reinforced discrimination task. Psychonomic Science, 1969, 14, 225-226.

CYLERT, L. A., MAYER, K. E., \& CHAPMAN, J. A. Effect of magnesium pemoline on learning and memory of a one-way avoidance response. Psychonomic Science, 1967, 7, 9-10.

FILBY, Y., SZARA, S., \& SALZMAN, B. Magnesium pemoline: Effect on acquisition and retention of discriminated avoidance behavior. Psychonomic Science, 1967, 9, 131-132.

FREY, P. W., \& POLIDORA, V. J. Magnesium pemoline: Effect on avoidance conditioning in rats. Science, $1967,155,1281$.

GLASKY, A. J., \& SIMON, L. N. Magnesium pemoline: Enhancement of brain RNA polymecoses. Science, $1966,151,702$.

GREEN, D. M. \& SWETS, J. A. Signal detection theory and psychophysics. New York: Wiley, 1966.

GUROWITZ, E. M., LUBAR, J. F., AIN, B. R., \& GROSS, D. R. Description of positive avoidance learning by magnesium pemoline. Psychonomic Science, 1967, 8, 19-20.

KULKARNI, A. S. Magnesium pemoline: Facilitation of instrumental avoidance learning. Psychonomic Science, 1967, 9, $39-40$.

LUBAR, J. F., BOITANO, J. J., GUROWITZ, E. M., \& AIN, B. R. Enhancement of performance in the Hebb-Williams maze by magnesium pemoline. Psychonomic Science, 1967, 7, 381-382.

PIZZI, W. J., \& SEE, C. S. Effects of magnesium pemoline on food and water intake on rats Psychonomic Science, 1968, 11, 101-102.

PLOTNIKOFF, N. Magnesium pemoline: Enhancement of learning and memory of a conditioned avoidance response. Science, 1966, 151, 703-704.

THOMPSON, R. W., \& KNUDSON, G. R. Magnesium pemoline: Facilitation of one way and two way avoidance learning. Psychonomic Science, 1968, 11, 155-156.

NOTES

1. The authors wish to thank L. Burgess for experimental assistance and Abbott Laboratories, Chicago, for supplying Cylert 30400. The authors are very grateful to Dr. Barrett Cooper, Purdue University, for supplying the raw data of his experiment for reanalysis.

2. Present address: Department of Psychology, Trent University, Peterborough, Ont., Canada. 